PIOTR KARWASIŃSKI

HANNA WESOŁOWSKA-MIS

Biblioteka Uniwersytecka w Poznaniu

\title{
Wpływ informatyzacji Biblioteki Uniwersyteckiej w Poznaniu na zmiany organizacyjne i rozwój usług bibliotecznych
}

\begin{abstract}
Streszczenie. W artykule omówiono zagadnienia związane z procesami informatyzacji Biblioteki Uniwersyteckiej w Poznaniu. W celu dokładnego scharakteryzowania przemian, prócz rysu historycznego, przedstawiono obszary, które wyraźnie poprawiły jakość pracy personelu i obsługę czytelników oraz przyczyniły się do poznania, upowszechniania i wdrażania nowoczesnych rozwiązań technologicznych. Zaprezentowano proces zmian $\mathrm{w}$ zakresie funkcjonowania systemu biblioteczno-informacyjnego Horizon i współpracy z narodowym katalogiem centralnym NUKAT. Opisano etapy rozwoju elektronicznej przestrzeni informacyjnej, w tym budowania elektronicznych zasobów wiedzy i tworzenia narzędzi do ich obsługi i wykorzystania $\mathrm{w}$ procesach wyszukiwania źródeł informacji. Zaprezentowano Bibliotekę Uniwersytecką jako partnera $\mathrm{w}$ aranżowaniu instytucjonalnych platform cyfrowych do deponowania i udostępniania dorobku intelektualnego społeczności naukowej Uniwersytetu im. Adama Mickiewicza w Poznaniu. Wskazano także funkcjonalność zaprojektowanych i wdrożonych innowacyjnych usług wirtualnych pakietu Libsmart, optymalizujących funkcjonowanie Biblioteki Uniwersyteckiej.
\end{abstract}

SŁowA KLuczowe: komputeryzacja, usługi wirtualne, chmura, biblioteka elektroniczna, użytkownicy wirtualni, Libsmart.

Strategia bibliotek akademickich od blisko 20 lat związana jest z rozwojem informatyzacji. Dopiero z perspektywy czasu dostrzec można mnogość zmian optymalizujących funkcjonowanie organizacji i ułatwiających czytelnikom korzystanie z bibliotecznego warsztatu naukowego, dzięki wykorzystaniu elektronicznych narzędzi i usług. Celem artykułu jest podsumowanie powyższych procesów w minionych 20 latach na przykładzie Biblioteki Uniwersyteckiej w Poznaniu - jednej z największych 
bibliotek akademickich w Polsce oraz czołowego ośrodka w implementacji technologii informatycznych.

W celu dokładnego scharakteryzowania przemian, prócz rysu historycznego wdrożenia komputeryzacji, wyodrębniono obszary, które wyraźnie poprawiły jakość pracy personelu i obsługę czytelników. Dane statystyczne zostały zebrane z modułów komputerowych systemów bibliotecznych, uruchomionych $\mathrm{w}$ systemie biblioteczno-informacyjnym UAM. Dzięki ich dokładnej rejestracji można założyć kierunek rozwoju Biblioteki w następnych latach, a także wskazać i przygotować bibliotekarzom te płaszczyzny funkcjonowania instytucji, które już teraz wymagają niezbędnych przekształceń.

\section{Komputeryzacja - nową erą bibliotek}

Za początek komputeryzacji bibliotek naukowych w Polsce, polegającej na zautomatyzowaniu rutynowych czynności i usług, przyjmuje się rok 1992, czyli datę implementacji pierwszego zintegrowanego systemu bibliotecznego VTLS.

Funkcjonowanie Biblioteki Uniwersyteckiej w Poznaniu do wspomnianego 1992 roku sprowadzało się głównie do działań opartych na manualnym systemie pracy. Wszelkie udoskonalenia bazowały na dobrze wypracowanym, tradycyjnym sposobie, zapoczątkowanym jeszcze w XIX wieku.

Inaczej kwestia przedstawiała się w bibliotekach na świecie, gdzie już w latach 80. XX wieku zaczęto wdrażać zautomatyzowany dostęp do informacji, w tym informacji naukowych, uzewnętrzniany przez kompleksową komputeryzację procesów bibliotecznych ${ }^{1}$. Równolegle z rozwojem zautomatyzowanego dostępu do źródeł wiedzy rozpowszechniły się nowe narzędzia pracy (mikrokomputery), pojawiły się dyski optyczne (CD-ROM), zaczęto wprowadzać zintegrowane technologie sieciowe.

W Polsce zmiany w sposobie funkcjonowania bibliotek związane były z przeobrażeniami w systemie polityczno-gospodarczym zapoczątkowanymi w 1989 roku. Przyczyniły się one między innymi do poznania, upowszechniania i wdrażania nowoczesnych rozwiązań technologicznych we wszystkich sferach funkcjonowania społecznego. Nie ominęły również bibliotekarstwa - wpłynęły na kształtowanie procesów automatyzacji bibliotek. Państwowe, naukowe biblioteki akademickie miasta Poznania,

${ }^{1}$ F.G. Kilgour, History of Library Computerization, „Information Technology and Libraries" 2013, nr 3 (3), s. 218-229. 
chcąc pełnić funkcje nowoczesnych ośrodków informacji i komunikacji, potrzebowały wsparcia instytucjonalnego i finansowego, niezbędnego do zainicjowania przemian technologicznych na wszystkich płaszczyznach działalności. Naprzeciw wspomnianym potrzebom wyszło Kolegium Rektorów Miasta Poznania. W związku z nowo powstałym Poznańskim Centrum Superkomputerowo-Sieciowym (PCSS) postanowiło wspomóc poznańskie środowisko naukowe i jak najszybciej wdrożyć dostęp do międzynarodowych zasobów bibliotecznych i informacyjnych służących transferowi wiedzy. Powołanie PCSS sprawiło, że środowisko akademickie oraz instytucje naukowe miasta Poznania otrzymały opiekę w zakresie zarządzania infrastrukturą sieciowo-informatyczną.

Realizacja planów kolegium rektorskiego była możliwa dzięki powołaniu specjalistycznego zespołu, do którego zadań należało opracowanie projektu automatyzacji bibliotek naukowych środowiska poznańskiego. Ustalono, że wspomniana grupa opracuje strategię finansową określająca potencjalne źródła wpływów, zasady finansowania przedsięwzięć oraz sprecyzuje założenia współpracy z partnerami zewnętrznymi, w tym z PCSS. Efektem prac powstałego zespołu było powołanie w październiku 1994 roku Poznańskiej Fundacji Bibliotek Naukowych (PFBN), z Radą Fundacji, zaś rok później ukonstytuowanie się Zgromadzenia Fundatorów reprezentowanego przez rektorów wyższych uczelni publicznych miasta Poznania oraz prezesów Poznańskiego Towarzystwa Przyjaciół Nauk i Oddziału PAN, a także dyrektora Biblioteki Raczyńskich². Zgromadzenie Fundatorów powołało Prezesa Poznańskiej Fundacji Bibliotek Naukowych i Zarząd. Akt notarialny o powołaniu PFBN podpisano 21 grudnia 1995 roku.

Z inicjatywy Zarządu PFBN we wrześniu 1997 roku zainicjowane zostało Porozumienie „Biblioteka z Horyzontem” skupiające krajowe biblioteki naukowe wykorzystujące ten sam system biblioteczno-informacyjny (Horizon). Jego celem były między innymi wzajemna pomoc w zakresie automatyzacji bibliotek, współorganizowanie szkoleń, utrzymanie wspólnych baz danych, koordynacja działań związanych z budową bibliotek cyfrowych, a po 2000 roku także współpraca w ramach projektu tworzenia Narodowego Katalogu Centralnego (NUKAT), czyli komputerowej bazy informującej o zasobach polskich bibliotek.

Rozwój i przeobrażenia technologiczne w polskich uczelniach wyższych wymusiły wzrost wydatków na inwestycje.

${ }^{2}$ J.A. Nikisch, Jakiego konsorcjum potrzebujemy i jakie mamy? Z doświadczeń Poznańskiej Fundacji Bibliotek Naukowych, „EBIB Elektroniczny Biuletyn Informacyjny Bibliotekarzy" 2002, nr 7 (36), http://www.ebib.pl/2002/36/nikisch.php [dostęp: 1.12.2015]. 
W styczniu 1996 roku, po okresie prawie rocznego testowania różnych oprogramowań biblioteczno-informacyjnych właściwych dla bibliotek naukowych, wybrano zintegrowany system Horizon firmy Ameritech, zbudowany w architekturze klient-serwer. Dostawcą systemu została firma Dynix GmbH z Niemiec. Przedstawicielstwo tej firmy w Polsce utworzono wkrótce w Poznaniu.

Skonfigurowanie sieci komputerowej, podłączenie do niej serwerów, stacji roboczych i terminali oraz instalacja oprogramowania stanowiły pierwszy etap komputeryzacji biblioteki, od którego rozpoczyna się jej nowa historia - jako hybrydy między warstwami tradycyjną i elektroniczną. Nie sposób w jednym artykule wyczerpać całego zagadnienia komputeryzacji biblioteki, gdyż dotyczy ona wszystkich sfer działalności instytucji. Z punktu widzenia organizacji i zarządzania zasobami oraz usługami można wyodrębnić kilka obszarów, które znacząco przeobraziły się, co skutkowało wzrostem jakości pracy personelu oraz usług oferowanych czytelnikom.

\section{Biblioteka nasycana sprzętem}

Sprawozdania z działalności Biblioteki Uniwersyteckiej z pierwszych lat komputeryzacji potwierdzaja, że informatyzacja działalności bibliotecznej została poprzedzona stworzeniem odpowiednich warunków sieciowo-sprzętowych. W ramach PFBN zakupiono i zainstalowano serwer do posadowienia bazy bibliotek Uniwersytetu im. Adama Mickiewicza oraz dostarczono 87 stacji roboczych.

W kolejnych latach praktyką Biblioteki Uniwersyteckiej stało się zabezpieczanie środków budżetowych na zakup lub wymianę sprzętu, a także przeprowadzanie regularnej aktualizacji specjalistycznego oprogramowania. Z bibliotecznych środków własnych przeznaczano środki na nowe zestawy komputerowe (komputer + monitor) i rozszerzano parametry techniczne wcześniej zakupionych (zwiększanie pamięci RAM, pojemności dysków). Pozyskiwano też urządzenia peryferyjne, w tym drukarki termiczne, terminale graficzne dla obsługi OPAC-u, skanery kodów kreskowych i drukarki sieciowe.

W latach 2001-2005 instalowano nowe wersje systemu operacyjnego Windows, przełączając je z serwera Novell na serwer domeny, a także dokonywano upgrade'u dotychczas stosowanego oprogramowania. W roku 2004 pojawił się w Bibliotece pierwszy rzutnik multimedialny, pomocny $\mathrm{w}$ realizacji potrzeb naukowo-dydaktycznych. 
Biblioteka prowadziła przez wiele lat serwerownię i odpowiadała za bezpieczeństwo przechowywanych danych, administrując własnym firewallem. Musiała więc ponosić koszty zapewnienia odpowiednich warunków zewnętrznych dla urządzeń zlokalizowanych na jej terenie, w tym bezawaryjnego działania klimatyzatorów i urządzeń podtrzymujących energię.

Nie zapomniano także o odpowiednim zapleczu dla użytkowników, przygotowano stanowiska komputerowe w czytelniach, wypożyczalni, katalogu i na korytarzach. Z czasem komputery stały się urządzeniami powszechnymi. Rozwinął się rynek notebooków, a w Bibliotece zaczęły pojawiać się osoby z osobistymi urządzeniami przenośnymi typu laptop, netbook. W tej sytuacji zadecydowano o zaprzestaniu dalszego nasycania przestrzeni dodatkowymi stacjonarnymi stacjami roboczymi, zadbano jednocześnie, aby w Informatorium bądź czytelniach użytkownicy otrzymali dostęp do dobrze wyposażonych stacji roboczych.

Dziś, po 20 latach od wdrożenia komputeryzacji, w Bibliotece Uniwersyteckiej zinwentaryzowanych jest blisko 190 komputerów, w tym 41 przeznaczonych dla czytelników. Dzięki programowi Envisionware użytkownicy chcący korzystać z bibliotecznej infrastruktury sprzętowej logują się numerem karty bibliotecznej i numerem PESEL. Po pozytywnej weryfikacji mogą rozpocząć nielimitowane korzystanie z komputerów, pracując na nich zgodnie z Zasadami korzystania z sieci komputerowej Biblioteki Uniwersyteckiej w Poznaniu, a więc w celach naukowych i służbowych. Ostatnie lata przyniosły dużą liberalizację przepisów bibliotecznych, dzięki czemu możliwe jest zapisywanie pracy własnej na pendrive'ach czy dyskach zewnętrznych, zaś dla tych, którzy chcą skopiować swoje prace, stworzono możliwość drukowania sieciowego. Po wysłaniu polecenia wydruku i zakończeniu pracy przy komputerze wystarczy udać się do Punktu Informacyjnego, opłacić usługę i odebrać zamówienie. W ten sposób udało się wyeliminować konieczność zakupu drukarek do każdej czytelni i pracowni.

Rok 2015 przyniesie w Bibliotece kolejną zmianę, tym razem w kwestii wypożyczeń międzybibliotecznych. W efekcie działań Biblioteki Narodowej została stworzona Academica - czyli cyfrowa wypożyczalnia międzybiblioteczna książek i czasopism naukowych. Odtąd zainteresowani użytkownicy, na przygotowanych przez Bibliotekę terminalach, w krótkim czasie uzyskują dostęp do kolekcji blisko 800000 dokumentów. 


\section{Horyzont zmian}

Podstawowym narzędziem pracy bibliotekarzy od 1997 roku jest komputerowy, wielomodułowy system biblioteczny Horizon. Jego uruchomienie zostało poprzedzone intensywnymi szkoleniami wszystkich bibliotekarzy zatrudnionych na uczelni. Cykle założonych szkoleń trwały do roku 2006. Na potrzeby szkoleniowe pracownicy Biblioteki opracowali wiele instrukcji opisujących sposoby postępowania i możliwości działań w obrębie komputerowych stacji roboczych oraz modułów zintegrowanego systemu Horizon.

Do celów szkoleniowych wyremontowano jedno z pomieszczeń BU i przystosowano na salę ćwiczeniowa, w której ustawiono osiem komputerowych stanowisk roboczych. Równocześnie, wraz z wprowadzeniem automatyzacji procesów bibliotecznych, na potrzeby użytkowników powołano do życia Sekcję Informacji Komputerowej przy Oddziale Informacji Naukowej (dziś: Oddział Informacji i Transferu Wiedzy).

System biblioteczno-informacyjny Horizon na przestrzeni ostatnich kilkunastu lat był wielokrotnie modyfikowany, co wynikało ze specyfiki pracy Biblioteki, stopnia rozwoju informatyzacji i zmieniających się preferencji użytkowników. Rdzeń programu, co prawda, zawsze stanowiły moduły gromadzenia, katalogowania i udostępniania tradycyjnych materiałów bibliotecznych, jednak dodatkowe opcje systemu wprowadzane od wersji 4.1, poprzez 4.2, 5.1, 5.3, aż po ostatnią 7.3.2 wspomagają bibliotekarzy w realizowanych zadaniach, tak by tam, gdzie to tylko możliwe, odciążać ich od czynności rutynowych.

Wdrożenie, sprawne funkcjonowanie i rozwój komputerowego systemu bibliotecznego możliwe są tylko dzięki ustalonej i prowadzonej strategii ${ }^{3}$. Użytkownik systemu, zarówno pracownik Biblioteki, jak i czytelnik korzystający z elektronicznego katalogu, musi otrzymać produkt w maksymalnym stopniu dostosowany do jego oczekiwań oraz, co niezmiernie ważne, także do aktualnych, międzynarodowych standardów ${ }^{4}$. Nad zapewnieniem tych warunków od 1996 roku czuwa bibliotekarz systemowy, będący administratorem odpowiedzialnym za podejmowanie decyzji w sprawach dotyczących programu, w tym modyfikacji parametrów, aktualizacji i wdrożeń związanych z systemem ${ }^{5}$. Ponieważ jest

${ }^{3}$ A.M. Cox, S. Corrall, Evolving academic library specialties, "Journal of the American Society for Information Science and Technology" 2013, nr 64 (8), s. 1526-1542.

${ }^{4}$ M.K. Bolin, Catalog design, catalog maintenance, catalog governance, "Library Collections, Acquisitions, and Technical Services" 2000, nr 24 (1), s. 53-63.

5 T.C. Wilson, The Systems Librarian: Designing Roles, Defining Skills, 1998, http:// search.ebscohost.com.ebookacademicsubscriptioncollection-worldwideidxi13031. 
on pośrednikiem między personelem Biblioteki a informatykami, jego kompetencje obejmują zarówno biegłą znajomość procesów bibliotecznych we wszystkich sferach jej działalności, jak i umiejętności informatyczne. W historii komputeryzacji Biblioteki Uniwersyteckiej w Poznaniu, w efekcie dynamicznie rozwijających się bibliotecznych usług elektronicznych, zaistniała konieczność wyraźnego wyodrębnienia grupy nadzorującej oprogramowanie biblioteczne - Zespołu Bibliotekarza Systemowego, później przemianowanego na Oddział ds. Systemu Biblioteczno-Informacyjnego. Pozostałym informatykom powierzono zadania techniczne, w tym obsługę serwerów, konfigurację stacji roboczych czy instalacje programów komputerowych.

Pierwsze lata komputeryzacji polskich bibliotek pokazały, że do ich sprawnego funkcjonowania i realizowania podejmowanych w nich zadań zintegrowane programy biblioteczne nie wystarczą. Bibliotekarze dość szybko doszli do przekonania, że systemy, poza tymi pisanymi na wyraźne zamówienie, nie spełnią wszystkich oczekiwań. Wynika to przede wszystkim z samej specyfiki programów, często dostosowywanych do określonych typów bibliotek, ich filozofii działania i wielkości zasobu. Po kilkunastoletniej obecności na polskim rynku oprogramowań bibliotecznych widać, że wszystkie łączy struktura modułowa oraz architektura klient-serwer. Równocześnie programy biblioteczne stanowią tylko bazę, wokół której lokalni informatycy tworzą dodatkowe aplikacje i dostosowują je do specyfiki funkcjonowania instytucji.

Personel Biblioteki Uniwersyteckiej w Poznaniu od pierwszych dni komputeryzacji realizował swoje zadania przy użyciu modułów gromadzenia, katalogowania i udostępniania, ale w każdym z nich przez lata dokonywano modyfikacji i usprawnień bądź projektowano i uruchamiano tzw. oprogramowania okołosystemowe.

Moduł gromadzenia rejestrował, co prawda, dostawców i nowe zamówienia, ale nie był dostosowany do obsługi wpływu z tytułu egzemplarza obowiązkowego. Brakowało rejestracji „drogi książki”, a także obsługi ubytków. Katalogerzy otrzymali do dyspozycji formularze obsługujące format MARC21, ale moduł nie dostarczał prezencyjnych personalnych statystyk opracowania zbiorów oraz narzędzi zapewniających eksport metadanych do zewnętrznych baz. Moduł udostępniania nadzorował proces rejestracji czytelników, ich wypożyczeń i zwrotów, ale w swej pierwotnej konfiguracji nie był dostosowany do specyfiki Biblioteki z tzw. magazynem zamkniętym - brakowało w nim obsługi zamówień elektronicznych.

bu-169.bu.amu.edu.pl/login.aspx?direct=true\&db=e000xww\&AN=45033\&site=ehostlive [dostęp: 1.12.2015]. 
W celu optymalizowania procesów bibliotecznych należało więc zaprojektować i uruchomić oprogramowania wspomagające. $\mathrm{W}$ minionych latach pojawiły się w Bibliotece m.in.:

- elektroniczny system drogi książki (rejestrujący przepływ materiałów bibliotecznych od wpływu do udostępnienia),

- baza ubytków (zapisująca etapy procesu usuwania materiałów bibliotecznych z inwentarza biblioteki),

- system zarządzania bazą dubletów,

- raporty o błędach w Horizonie,

- program do tworzenia drukowanej księgi inwentarzowej.

W zakresie obsługi użytkowników wdrożono:

- programy rejestrujące odwiedziny czytelników,

- statystykę wykorzystywania materiałów bibliotecznych z tzw. wolnego dostępu,

- system umożliwiający wydruk monitów,

- wysyłanie elektronicznych przypomnień do czytelników.

Niestety od pewnego czasu liczba aplikacji i skryptów zdecydowanie przerasta możliwości systemu Horizon, co rodzi pytania o przyszłość dalszej współpracy z firmą SirsiDynix, producentem oprogramowania Horizon, deklarującym usługi dla bibliotek.

Praca w programie bibliotecznym od 15 lat wygląda bardzo podobnie. Personel Oddziału Gromadzenia opatruje egzemplarze podobnymi etykietami, nie zmieniła się zasadniczo filozofia formatu MARC21, a więc trudno oczekiwać rewolucyjnych zmian w sferze katalogowania. Nie sposób jednak, przy okazji omawiania tematu nowoczesnego opracowania zbiorów, nie wspomnieć o przełomie, jakim było uruchomienie w 2002 roku Narodowego Uniwersalnego Katalogu (NUKAT). Platforma ta związana jest z dziedziną informatyzacji w kwestii zarówno ustandaryzowanego formatu opracowania, jak również dostosowania infrastruktury sprzętowej i programistycznej umożliwiającej wymianę metadanych, a więc eksport bądź import rekordów bibliograficznych i haseł wzorcowych (KABA), import modyfikacji, dodawanie bądź usuwanie siglum Biblioteki. Współpraca z NUKAT-em przynosi Bibliotece wymierne korzyści, umożliwia katalogerom pobieranie opisów i haseł z ogólnopolskiej bazy - skraca czas opracowywania materiałów bibliotecznych i przyspiesza ich udostępnianie czytelnikom. Biblioteka Uniwersytecka, przystępując do NUKAT-u, podjęła decyzję o partnerstwie czynnym, a więc równoczesnym uzupełnianiu bazy katalogowej opisami bibliograficznymi z własnego, nierzadko unikatowego księgozbioru. Zwiększa to niewątpliwie prestiż instytucji i promuje bardzo dobrze wykwalifikowany personel. Praca dla katalogu NUKAT wymusza znajomość dwóch 
systemów bibliotecznych - lokalnego oraz programu VIRTUA/VTLS, obsługującego katalog centralny ${ }^{6}$. Duże rozbieżności między nimi, takie jak chociażby inna struktura bazy, kodowanie znaków, a nawet zapis formatu danych, w ciągu ponad dziesięciu lat działania katalogu centralnego, przysparzają wielu trudności administratorom i pracownikom, którzy na co dzień zmuszeni są konwertować opisy i hasła celem zachowania poprawności wyświetlania danych. Biblioteka potrzebuje również stałego wsparcia programistów, gdyż tzw. konwertery trzeba modyfikować po każdej wprowadzonej zmianie $\mathrm{w}$ formacie MARC21.

W pierwszych latach współpracy z NUKAT-em bibliotekarze posiłkowali się pobieraniem opisów i haseł z kopii bazy katalogu centralnego posiadanej przez Bibliotekę Uniwersytetu Mikołaja Kopernika w Toruniu. Działo się to do momentu wprowadzenia Horizona w wersji 7.3, na którą nie zdecydowała się biblioteka toruńska. Dziś biblioteka ta posiada własne oprogramowanie (Cham2Hor), jest bardziej niezależna, a wartością dodaną jest fakt, że wszyscy bibliotekarze bibliotek wydziałowych otrzymali możliwość importu danych.

W omówieniu rozwoju komputerowego systemu bibliotecznego nie można pominąć centralnej roli Biblioteki Uniwersyteckiej w systemie biblioteczno-informacyjnym Uniwersytetu im. Adama Mickiewicza w Poznaniu. Automatyzowanie działań bibliotecznych polegało na żmudnym procesie scalania księgozbiorów małych bibliotek zakładowych, katedralnych i tworzenia z nich dużych - wydziałowych. Dzięki ujednolicaniu technik bibliotecznych przy równoczesnym wsparciu wszystkich uczelnianych jednostek bibliotecznych Uniwersytet posiada najbardziej skomputeryzowaną sieć biblioteczno-informacyjną w Polsce. Dziś we wszystkich 22 lokalizacjach systemowych personel opracowuje książki, zakłada elektroniczne konta czytelnika, rejestruje wypożyczenia i zwroty oraz udostępnia usługi rezerwacji, czy też zamówień magazynowych. Rolą Biblioteki Uniwersyteckiej jest codzienne administrowanie programem bibliotecznym w każdej jednostce, w tym także instalacja oprogramowania, konfiguracja modułów, przydzielanie uprawnień pracownikom, zarządzanie kolekcjami oraz wprowadzanie parametrów do tablic bazy danych i prowadzenie szkoleń.

Warsztaty z bibliotekarzami obejmują zarówno przysposabianie młodych pracowników do pracy w modułach, przez zapoznawanie ich z modyfikacjami oprogramowania, rozszerzaniem oferty usługowej, jak również bardzo szczegółowe konsultacje dotyczące zmian w zakresie

${ }^{6}$ H. Hollender, A. Kasprzyk, Library cooperation the Polish way: toward NUKAT and WorldCat in Poland, „New Library World” 2008, nr 109 (9/10), s. 457-465. 
gromadzenia czy opracowania zbiorów. Cieszy fakt, że władze wydziałów, świadome konieczności wdrażania technologicznych innowacji, wspierają własne biblioteki w nasycaniu sprzętem komputerowym i wpisują ich rozwój informatyczny do aplikacji grantowych i składanych projektów europejskich. Dzięki temu już kilka z nich może się pochwalić wdrożeniem usług samodzielnego wypożyczania i zwrotu materiałów bibliotecznych z wykorzystaniem technologii RFID (Radio-frequency identification). Działanie to, co prawda, wymusiło konieczność dostosowania infrastruktury programistycznej ${ }^{7}$ czy też inwestycji w etykietowanie materiałów bibliotecznych, wymianę kart bibliotecznych dla pracowników naukowych i doktorantów na nośniki z wewnętrznym chipem „mifarowym", jednak w konsekwencji usamodzielniło czytelnika i odciążyło pracowników od rutynowych czynności udostępniania zbiorów.

\section{E-użytkownik}

Ostatnie 15 lat funkcjonowania Biblioteki Uniwersyteckiej zmieniły jej wizerunek w oczach czytelników, o czym świadczą statystyki i wskaźniki jakości udzielanych usług. Doskonałym przykładem może być ewolucja bibliotecznego katalogu online. Pierwotnie był on dostępny lokalnie, na terminalach w gmachu Biblioteki. Rozwój internetu spowodował konieczność stworzenia, dziś wyglądających nieco archaicznie, pierwszych katalogów webowych, z prezentacją skatalogowanego zasobu bibliotecznego. $Z$ czasem pojawiły się $\mathrm{w}$ nim opcje sprawdzania elektronicznego konta czytelnika i rejestru wypożyczeń.

Rok 2004 przyniósł kolejną rewolucyjną zmianę - uruchomienie usługi elektronicznych zamówień i rezerwacji. Fakt, że przez katalog online można złożyć zdalne zamówienie i zostać poinformowanym mailowo o jego realizacji, stanowił pierwszy etap wirtualizacji usług. Odtąd użytkownik może korzystać ze swojej biblioteki przez całą dobę, bez konieczności pojawiania się w budynku wypożyczalni.

Wprowadzanie elektronicznych usług bibliotecznych wymusza stwarzanie odpowiednich warunków technicznych oraz opisywania szczegółowych procedur udzielania usług. W przypadku e-zamówień niezbędne okazały się: zakup drukarki, tonerów, papieru, stworzenie aplikacji do

7 D. Caldwell-Stone, Chapter 6: RFID in Libraries, "Library Technology Reports” 2010, nr 46 (8), s. 38, http://search.ebscohost.com.academicsearchcompleteidesx11478. bu-169.bu.amu.edu.pl/login.aspx?direct=true\&db=f5h\&AN=55483467\&site=ehostlive [dostęp:]. 
automatycznego generowania formularzy, odpowiednia konfiguracja modułu udostępniania. Równolegle zapoznano personel z procesem rejestracji zamówień i ich odnotowywania przez system oraz $z$ warunkami realizacji bądź usuwania dezyderatów przeterminowanych. Statystyki pierwszych tygodni funkcjonowania usługi dowiodły, że jej wdrożenie przyniosło zysk (mimo poniesionych kosztów inwestycji). Dziś, po dziesięciu latach funkcjonowania e-zamówień i e-rezerwacji prawie $100 \%$ zamówień bibliotecznych pochodzi z katalogu online. Pojawiła się też dodatkowa korzyść dla Biblioteki - zmniejszenie liczby zamówień niezrealizowanych.

W latach 2004-2010 w zakresie obsługi użytkowników kontynuowano niwelowanie ograniczeń biblioteki tradycyjnej i ujednolicano zasady funkcjonowania systemu biblioteczno-informacyjnego UAM. Wprowadzono elektroniczne przypomnienia dla czytelników o zbliżającym się terminie zwrotu książek. Dzięki wspólnej bazie bibliotek zrzeszonych w Poznańskiej Fundacji Bibliotek Naukowych i pracujących w tym samym systemie bibliotecznym czytelnicy uzyskali możliwość otrzymywania potwierdzeń o braku zaległości we wszystkich jednostkach należących do PFBN. Dzięki wspólnej bazie zmniejszyła się liczba parametrów odpowiedzialnych za limitowanie wypożyczeń. Umożliwiono czytelnikom dokonywanie zdalnych prolongat terminu zwrotu książek, bez konieczności docierania do wypożyczalni z uprzednio wypożyczonymi egzemplarzami.

W Bibliotece Uniwersyteckiej pojawiła się również sieć bezprzewodowa, co zaowocowało zwiększoną liczbą odwiedzin użytkowników przychodzących z własnymi laptopami. Fakt ten spowodował zmiany strategii Biblioteki w zakresie nasycania jej sprzętem komputerowym dla czytelników. Zamiast na zwiększanie liczby komputerów środki przeznaczano na bezpłatne udostępnianie trzech najnowocześniejszych, samoobsługowych skanerów dla użytkowników.

Komputeryzacja procesów bibliotecznych to ciągłe zadawanie pytania, czy jest szansa na większe uproszczenie czynności bibliotecznych bibliotekarza i czytelnika ${ }^{8}$. Skoro Biblioteka zakłada użytkownikowi elektroniczne konto w module udostępniania, to fakt obecności w bibliotecznej czytelni może być ewidencjonowany w bazie elektronicznej. Odnotowana w niej kategoria czytelnika i data odwiedzin dostarczają danych statystycznych - kto korzysta z Biblioteki, a więc na jaką grupę odbiorców ukierunkowywać działania strategiczne, a którą zachęcać do czerpania

${ }^{8}$ S.Q. Yang, H.A. Dalal, Delivering Virtual Reference Services on the Web: An Investigation into the Current Practice by Academic Libraries, "The Journal of Academic Librarianship" 2015, nr 41 (1), s. 68-86. 
z jej bogatego zestawu usług. Spośród wielu udogodnień wdrożonych w pierwszej dekadzie XXI wieku na uwagę zasługuje sprawdzanie historii wypożyczeń i zamówień, możliwość przeprowadzania e-skontrum na podstawie aktualnego wykazu kolekcji czy też analiza wykorzystania egzemplarzy przez użytkowników. Zasadniczą cechą powyższych programów jest skracanie dystansu między klientem (zewnętrznym i wewnętrznym) organizacji a poszukiwaną przez niego informacją, dzięki wykorzystaniu dostępnej technologii.

\section{Elektroniczne źródła informacji}

Kolejnym aspektem komputeryzacji jest organizacja i administracja informacją elektroniczna, z której coraz powszechniej korzystają współcześni użytkownicy. Biblioteki od momentu pojawienia się w Polsce kolekcji zasobów elektronicznych, w postaci e-czasopism, baz danych czy e-booków, prześcigają się w subskrybowaniu jak największej ich liczby, gdyż ta przynosi prestiż i dobrą pozycję w rankingach uczelni wyższych. Prawidłowe organizowanie tego zasobu powinno się jednak wyrażać w utrzymaniu proporcji między wielkością a realnym wykorzystaniem. Dopiero wtedy środki przeznaczane na gromadzenie wydatkowane są racjonalnie.

Biblioteka Uniwersytecka w Poznaniu dość szybko otworzyła się na organizowanie dostępu do kolekcji elektronicznych i wkrótce stała się czołowym ośrodkiem w dostarczaniu użytkownikom tego nowoczesnego warsztatu naukowego. Musiała jednak zmierzyć się z uwarunkowaniami prawnymi i technicznymi, bowiem większość subskrybowanych zasobów udostępnianych jest na licencjach udzielanych przez wydawnictwa Uniwersytetowi im. Adama Mickiewicza. Rolą Biblioteki stało się zabezpieczanie zasobu i dokładanie starań o respektowanie przepisów prawa autorskiego. Realizując postanowienia umów z wydawcami, bazy i czasopisma udostępniano pierwotnie pracownikom i studentom UAM stacjonarnie, w Czytelni Oddziału Informacji Naukowej. Precyzyjnie określano czas, w którym mogą oni korzystać z komputerów, i zwracano uwagę, czy nie zgrywają zbyt wielkiej liczby danych. Z czasem lokalne korzystanie z elektronicznego warsztatu okazało się dla odbiorców usług zbyt uciążliwe, stąd Biblioteka zaczęła poszukiwać sposobu, który umożliwiłby zdalne łączenie się z platformami baz. Takie rozwiązanie pojawiło się w roku 2005, kiedy uruchomiono system HAN (H\&H). Do dziś pełni on dwojaką funkcję: jest serwerem proxy umożliwiającym sprawdzanie uprawnień czytelnika oraz narzędziem rejestrującym bardzo dokładne 
statystyki wykorzystywania kolekcji. Identyfikacja czytelnika jest możliwa dzięki pełnej integracji systemu HAN z komputerowym system bibliotecznym Horizon. W jego bazie wprowadzono modyfikację polegającą na oznaczaniu, która kategoria czytelnika ma uprawnienia do korzystania z zasobów licencjonowanych. Równocześnie $\mathrm{w}$ momencie logowania się przez numer karty bibliotecznej i numer PESEL system HAN sprawdza stan aktualizacji konta bibliotecznego na bieżący rok akademicki i weryfikuje brak blokad na koncie użytkownika. Zbierane przy tej okazji dane statystyczne pozwalają określić liczbę wejść do poszczególnych kolekcji bądź tytułów i czas spędzony na platformie. Dzięki jednolitej metodologii dane te mogą służyć dysponentom środków do podejmowania decyzji o kontynuacji bądź zaprzestaniu subskrypcji.

W celu dotarcia do elektronicznego katalogu lub kolekcji źródeł elektronicznych użytkownik najczęściej korzysta z bibliotecznej strony internetowej ${ }^{9}$. W ciągu ostatnich lat bardzo zmieniła się filozofia tworzenia witryn, gdyż oprócz warstwy technologicznej stronę stricte informacyjną (z rozbudowaną informacją o historii biblioteki, opisem najciekawszych kolekcji bądź strukturą organizacyjną) zastąpiła "brama wiedzy”. Niewątpliwie duże znaczenie $\mathrm{w}$ tym przeobrażeniu miał dynamiczny wzrost liczby e-zasobów i elektronicznych usług bibliotecznych, a także konieczność stworzenia miejsca w przestrzeni cyfrowej do ich prezentacji.

Strona internetowa Biblioteki Uniwersyteckiej zawsze była dostosowana do aktualnych standardów światowych. W ostatnich 20 latach pojawiły się trzy wersje tej strony - dwie pierwsze tworzone w HTML, a obecna zbudowana na podstawie technologii CMS. Na podkreślenie zasługuje przejrzystość, estetyka i logistyka informacji. Nie można byłoby tego osiagnnąć, gdyby nie profesjonalne wsparcie webmastera oraz bieżący, codzienny kontakt między nim a redaktorem strony. Dziś strona Biblioteki to potężny portal informacyjny, aktualizowany w systemie 24h, zawierający wiadomości o instytucji, jej misji, historii, strukturze, ale przede wszystkim to integrator ułatwiający dostęp do elektronicznych źródeł informacji. Corocznie platforma jest odwiedzana ponad 800000 razy, oprócz użytkowników z Polski odnotowano także gości z Niemiec, Holandii, Stanów Zjednoczonych, Wielkiej Brytanii, Francji i Ukrainy.

Widząc szerokie zainteresowanie portalem ze strony użytkowników obcojęzycznych, podjęto decyzję o prowadzeniu portalu równolegle w dwóch wersjach językowych - polskiej i angielskiej. Redakcją strony zajmuje się pięciu bibliotekarzy odpowiedzialnych za organizację,

${ }^{9}$ N. Aharony, An analysis of American academic libraries' websites: 2000-2010, „The Electronic Library" 2012, nr 30 (6), s. 764-776. 
dobór i selekcję informacji oraz korektę i tłumaczenie tekstów. W celu zapewnienia najwyższych wskaźników jakości witryny jej profesjonalne prowadzenie od strony technicznej powierzono firmie outsourcingowej.

\section{Biblioteka w pełni wirtualna}

Lata 2010-2014 to dla Biblioteki Uniwersyteckiej etap wirtualizowania usług bibliotecznych, a więc projektowania, przygotowywania i uruchamiania pionierskich w Polsce programów, dzięki którym potencjalny czytelnik może korzystać z e-biblioteki bez konieczności przychodzenia do jej gmachu. Biblioteki wychodzą z dotychczasowych ram i schematów, podejmując zadania z zakresu digitalizacji, e-komunikacji czy też bankowości elektronicznej. Podstawową grupę produktów zmieniających wizerunek Biblioteki stanowią aplikacje pakietu Libsmart.

Geneza powstania pierwszej z nich - Libsmart Payment - sięga roku 2010. Pojawiła się wówczas idea, aby wszystkie opłaty naliczane $\mathrm{w}$ module udostępniania $\mathrm{z}$ tytułu nieterminowego zwrotu materiałów bibliotecznych mogły być regulowane z wykorzystaniem bankowości elektronicznej użytkownika.

Libsmart w swojej filozofii ma na celu wykorzystywanie technologii tam, gdzie to możliwe, przez dostarczenie użytkownikowi intuicyjnego narzędzia, z którego pomocą w prosty sposób, bez skomplikowanych instrukcji i szkoleń, zrealizuje większość czynności bibliotecznych. Samo wdrożenie miało być również dowodem na to, że są jeszcze nieodkryte obszary funkcjonowania biblioteki, z którymi warto się zmierzyć. Ponieważ wdrożenie płatności elektronicznych było na Uniwersytecie im. Adama Mickiewicza rozwiązaniem pionierskim, przed uruchomieniem usługi trzeba było zbadać możliwości prawne, przeprowadzić proces legislacyjny, zagwarantować środowisko techniczne oraz finalnie zaprojektować aplikację kompatybilną z komputerowym system bibliotecznym Horizon. W grudniu 2011 roku, po wielu testach, oddano użytkownikom gotowy produkt, który natychmiast spotkał się z dużym zainteresowaniem.

Sukcesem Payement jest jego integracja z modułem udostępniania, możliwość uiszczania opłat w systemie $24 \mathrm{~h}$, natychmiastowe usuwanie blokad z konta czytelnika i przywracanie mu pełnych uprawnień, szczególnie do korzystania z elektronicznych usług bibliotecznych.

Równolegle z tworzeniem Libsmart Payment Oddział ds. Systemu Biblioteczno-Informacyjnego przygotowywał kolejne udogodnienie dedykowane głównie osobom spoza Poznania i Wielkopolski, a zaintereso- 
Tabela 1. Libsmart Payment - zainteresowanie użytkowników

\begin{tabular}{|l|c|c|c|c|}
\hline & 2011 & 2012 & 2013 & 2014 \\
\hline Liczba wpłat & 236 & 3789 & 5775 & 8263 \\
\hline Kwota wpłat kary (w zł) & 4299,2 & 50084,8 & 70250,1 & 96968 \\
\hline
\end{tabular}

wanym bogatymi kolekcjami tradycyjnych materiałów bibliotecznych. Libsmart Copy stanowiło przełom w prowadzeniu działalności reprograficznej dla użytkownika indywidualnego. Projekt aplikacji przygotowany został po zapoznaniu się z uwagami i sugestiami co do pożądanego sposobu zamawiania cyfrowych kopii z fragmentów książek i artykułów z czasopism. Dostęp do aplikacji możliwy jest wprost z katalogu elektronicznego, po jednorazowej procedurze rejestracji. Baza użytkowników jest niezależna od bazy komputerowego systemu bibliotecznego. Umożliwia składanie zamówień przez zainteresowanych z całego świata. Formularz pobiera dane bibliograficzne $\mathrm{z}$ bazy systemu Horizon, zaś proces realizacji zgłoszenia dokonywany jest $\mathrm{w}$ trzech etapach:

- wyceny zlecenia przez operatora usługi i zatwierdzenia kosztorysu przez użytkownika,

- wykonania, a więc zeskanowania fragmentu książki lub czasopisma i zamieszczenia kopii na serwerze,

- dokonania płatności i pobrania tekstu przez zamawiającego.

Tabela 2. Libsmart Copy - zaintersowanie użytkowników

\begin{tabular}{|l|c|c|c|}
\hline & 2012 & 2013 & 2014 \\
\hline Liczba wpłat & 357 & 2166 & 1942 \\
\hline Kwota wpłat kary (w zł) & $3910,6 \mathrm{zł}$ & $22087,4 \mathrm{zł}$ & $19088,2 \mathrm{zł}$ \\
\hline
\end{tabular}

Autorzy aplikacji zadbali również o zabezpieczanie pliku przed łamaniem prawa autorskiego, wprowadzili funkcję wystawiania faktur dla firm oraz informowania mailowego o każdym etapie realizacji zamówienia. W przypadku Libsmart Copy Bibliotekę zaskoczyła ogromna przychylność użytkowników, którzy podkreślają że sukcesem programu, prócz aspektu technologicznego, jest błyskawiczne wykonanie usługi.

Biblioteka Uniwersytecka w Poznaniu znana jest w polskim środowisku bibliotekarskim z uruchomienia uniwersalnej platformy komunikacyjnej do prowadzenia usługi Ask a librarian (Zapytaj bibliotekarza).

Od 2010 roku dotychczasową stronę WWW, zespalającą kilka kanałów komunikacyjnych, zastąpił profesjonalny system dedykowany wyłącznie 
bibliotekom ${ }^{10}$. Użytkownik ma możliwość wyboru preferowanego kanału komunikacji wirtualnej: chat, helpdesk, mail i natychmiast kieruje swoje pytanie do Centrum Obsługi Użytkownika. Dyżurujący konsultanci udzielają informacji z poziomu modułu operatora, mając do dyspozycji bazy wspomagające: najczęściej zadawanych pytań (FAQ) czy też poszukiwanych przez użytkowników adresów internetowych. Wszystkie zgłoszenia odnotowane są w bazie danych, a dzięki jednolitej kategoryzacji pytań i użytkowników tworzy się profesjonalna statystyka udzielania e-informacji. Każdego roku przez system Libsmart Assistant kierowanych jest ponad 5500 zapytań od użytkowników z poznańskiego środowiska akademickiego, a także z Polski i zagranicy.

W roku 2013 w Bibliotece uruchomiono autorski system Libmsart Remainder dotyczący wysyłania mailowych przypomnień o zwrotach książek. Wdrożony produkt jest rozwiązaniem doskonalszym od tych, które proponują producenci systemów bibliotecznych, ponieważ wysyła przypomnienia tydzień oraz trzy dni przed określoną datą zwrotu, a następnie monity 7, 14 i 21 dni po jej przekroczeniu i odnotowuje fakt wysyłki w bazie danych. Ponadto program uwzględnia w swym kodzie możliwość pojawiania się ewentualnych problemów technicznych, zakłócających dostarczanie wiadomości czytelnikom, a także pozwala bibliotekarzom generować papierowe monity dla grupy, która nie podała adresu e-mail do swojego konta czytelnika.

Libmsart Remainder jest w pełni zintegrowany z systemem bibliotecznym, stąd po wysłaniu ostatniego monitu aplikacja blokuje uprawnienia czytelnika do korzystania z tradycyjnych i elektronicznych zasobów bibliotecznych, aż do uregulowania zobowiązań wobec Biblioteki. Technologia informatyczna w tym przypadku przynosi oszczędności związane z wysyłką pocztową papierowych monitów. Zgodnie ze zmianami dokonanymi w regulaminie określającym szczegółowe zasady korzystania z systemu biblioteczno-informacyjnego UAM w przypadku przekazania przez czytelnika Bibliotece swojego adresu mailowego jedyną formą dostarczania przypomnień i monitów jest forma elektroniczna. Równocześnie, porównując wcześniejszą praktykę kwartalnego bądź półrocznego wysyłania informacji o zaległościach, po wprowadzenia Remainder codziennie z serwerów bibliotecznych eksportowanych jest ponad 600 wiadomości mailowych.

${ }^{10}$ P. Karwasiński, E. Karwasińska, Libsmart Assistant - nowy standard komunikacji bibliotecznej w przestrzeni wirtualnej, w: IV Wroctawskie Spotkania Bibliotekarzy. Z problemów bibliotek naukowych Wrocławia 11, red. D. Dudziak, M. Ziółek, Wrocław 2014, s. $57-74$. 
Kluczem spinającym dotychczasowe elementy całego pakietu Libsmart było wprowadzenie w 2014 roku systemu zdalnego zapisu i aktywacji kont czytelniczych przez system Libsmart Register. W tym przypadku program komputerowy połączony został nie tylko z bazą Horizon, lecz także z Uniwersyteckim Systemem Obsługi Studiów (USOS) i zintegrowanym systemem zarządzania uczelnią - AXAPTA. Aplikacja w kilku prostych krokach sprawdza fakt uprzedniej rejestracji $\mathrm{w}$ bazie czytelników i proponuje użytkownikowi zapis bądź wyłącznie aktywację konta na bieżący rok akademicki. Przez system Register, z którego mogą korzystać zainteresowani z całego świata, można dokonać opłaty aktywacyjnej, wykorzystując bankowość elektroniczną. Natychmiast po uiszczeniu opłaty automat nadaje odpowiednie uprawnienia czytelnikowi i czyni jego konto aktywnym. Procedura ta trwa zaledwie kilka minut i wyklucza konieczność potwierdzania faktu aktualizacji w wypożyczalni.

Bogata funkcjonalność, intuicyjność nawigacji, powszechna dostępność czynią z programów Libsmart doskonałe narzędzia wspomagające obsługę użytkownika wirtualnego, na którego Biblioteka Uniwersytecka w Poznaniu szczególnie ukierunkowuje swoje działania strategiczne. Wraz z rozwojem technologii mobilnych dzisiejsi użytkownicy zabiegają o dostęp do zasobów i usług swojej biblioteki za pośrednictwem smartfonów czy tabletów. Być może nie chca już do biblioteki przychodzić, ale tam, gdzie to tylko możliwe, łączyć się z nią przez całą dobę ${ }^{11}$. Na takie oczekiwania trzeba odważnie odpowiadać i przekonywać społeczeństwo, że to kolejny etap informatyzacji bibliotek.

\section{Partnerstwo dla wiedzy}

Omawiając temat komputeryzacji, trzeba podkreślić rolę Biblioteki $\mathrm{w}$ przedsięwzięciach służących rozwojowi informacji elektronicznej. $\mathrm{Na}$ przestrzeni ostatnich kilkunastu lat należy wyodrębnić kilka obszarów, w których Biblioteka Uniwersytecka upowszechnia naukę, buduje własne zasoby wiedzy oraz koordynuje projekty, dzięki którym uczelnia awansuje w międzynarodowych rankingach szkół wyższych.

Chronologicznie pierwszymi działaniami Biblioteki wykorzystującymi informatyzację do opracowywania swoich kolekcji, poza retrokonwersją zasobu, było tworzenie komputerowych bibliograficznych baz danych.

${ }^{11}$ A.S. Chow, R.A. Croxton, A Usability Evaluation of Academic Virtual Reference Services, „College \& Research Libraries” 2014, nr 75 (3), s. 309-361. 
Stworzony w 1999 roku Spis Zawartości Prasy Wielkopolskiej XIX i XX wieku to elektroniczna odsłona uprzedniej wersji papierowej, zawierająca informacje o artykułach z prawie 40 tytułów czasopism regionalnych przechowywanych w magazynach bibliotecznych.

Początkowo biblioteczne bazy danych tworzono w języku HTML, w którym napisana jest większość stron WWW. Z czasem hipertekstowy język znaczników został zastąpiony przez system EXPERTUS, z bogatszymi narzędziami indeksującymi oraz umożliwiającymi tworzenie i eksportowanie list podręcznych.

Do działań popularyzujących informację biblioteczno-bibliograficzną można zaliczyć budowany od 2003 roku portal Dokumentów Życia Społecznego Wielkopolski, z danymi statystycznymi o kolekcjach, z ponad 80 jednostek kulturalnych regionu. Biblioteka Uniwersytecka podjęła się koordynacji projektu i nadzoruje stałą aktualizację informatora.

Nie można pominąć również takich przedsięwzięć jak realizowany $\mathrm{w}$ poznańskim środowisku bibliotecznym klaster prawno-ekonomiczny EKONLEX, czy Spis Gazet Polskich Okresu Międzywojennego (1918-1939) znajdujących się w zbiorach Biblioteki Uniwersyteckiej w Poznaniu, stanowiący odpowiedź na postulaty złożone w 2006 roku, w trakcie poznańskiej konferencji naukowej „Gazety. Zasoby. Opracowanie. Ochrona. Digitalizacja. Promocja/Informacja”.

W roku 2000 w strukturze Biblioteki Uniwersyteckiej utworzono Pracownię Mikrofilmowa, w której podjęto zadanie tworzenia własnych zasobów cyfrowych, a więc mikrofilmowania i digitalizacji tradycyjnych materiałów bibliotecznych w celu ich ochrony i szerszego udostępniania. Dziś dzieło to stanowi jeden z priorytetów funkcjonowania Biblioteki, która będąc głównym deponentem Wielkopolskiej Biblioteki Cyfrowej, przekazała do prezentacji ponad 107000 obiektów. Wszystkie materiały z zakresu dziedzictwa kulturowego i regionaliów dostępne są w modelu open access, indeksowane przez najważniejsze światowe wyszukiwarki, co zwiększa liczbę korzystających z tego zbioru.

Wraz z rozwojem technologii zapisu danych zmieniły się zadania i rola Pracowni Mikrofilmowej. Dostępność i popularność płyt CD i CD-ROM, przeznaczonych do zapisu danych z zakodowaną cyfrowo informacja do bezkontaktowego odczytu światłem lasera optycznego, nadały nowy kształt działaniom pracowni. Mikrofilmowanie stało się działaniem archiwizacyjnym dokumentów, które w oryginalnej postaci są wielkimi arkuszami. Dlatego Pracownię Mikrofilmową od połowy 2012 roku przemianowano na Oddział Digitalizacji, w którego skład wchodzi również Pracownia WBC. Oddział Digitalizacji w obecnej postaci wymaga stałych nakładów na rozwój technologiczny, a więc zakupu wielkoformatowych 
skanerów, streamerów do długookresowej archiwizacji czy też oprogramowania graficznego.

Niezbędne jest też regularne szkolenie pracowników z zakresu zachowywania aktualnych standardów opracowania danych cyfrowych w formacie Dublin Core. Kataloger ma świadomość spoczywającej na nim odpowiedzialności za tworzone opisy bibliograficzne, gdyż te dzięki protokołom wymiany danych natychmiast są widoczne w ogólnopolskiej multiwyszukiwarce Federacji Bibliotek Cyfrowych, a za jej pośrednictwem w europejskiej bibliotece cyfrowej Europeana.

Biblioteka Uniwersytecka nie ustaje w wysiłkach pozyskiwania środków zewnętrznych na działania związane z digitalizacją. W ciągu ostatnich sześciu lat udało się zdobyć i zrealizować grant z Ministerstwa Kultury i Dziedzictwa Narodowego w ramach Programu Operacyjnego „Dziedzictwo Kulturowe” - Tworzenie zasobów cyfrowych dziedzictwa kulturowego na realizację projektu „Digitalizacja i medializacja XIX-wiecznej prasy wielkopolskiej”. W latach 2011-2013 zeskanowano wszystkie katalogi kartkowe, dzięki czemu informacja o całym zasobie bibliotecznym znajduje się w internecie. Dla użytkowników zaprojektowano specjalną przeglądarkę umożliwiającą przeszukiwanie tradycyjnego katalogu, elektroniczne zamawianie dokumentów do czytelń. Dzięki wspomnianemu systemowi bibliotekarze mogą dokonywać skontrum księgozbioru. W roku 2011 pozyskano środki z Ministerstwa Nauki i Szkolnictwa Wyższego w ramach Działalności Upowszechniającej Naukę na wyselekcjonowanie i poddanie cyfryzacji pięciu tytułów z kolekcji regionalnych czasopism Wielkopolski przełomu XIX i XX wieku.

Biblioteka rozpoczęła również intensywną promocję internetową swoich zasobów ikonograficznych w uruchomionej i sukcesywnie napełnianej bazie Wielkopolskiej Kolekcji Ikonograficznej - WIEKI. Prezentuje w niej cyfrowe wersje fotografii, kart pocztowych i albumów przechowywanych w Oddziale Zbiorów Specjalnych, umożliwiając dodatkowo zdalny zakup cyfrowej reprografii do wykorzystania komercyjnego.

Dzięki bardzo dobremu zapleczu technologicznemu oraz wykwalifikowanemu w zakresie digitalizacji personelowi Biblioteka włącza się do realizacji projektów prowadzonych przez inne uczelnie bądź jednostki naukowe i kulturalne, zaś uzyskane środki przeznacza na utrzymanie, konserwację i rozbudowę pracowni. Światowa moda na cyfryzację, szczególnie dziedzictwa kulturowego i materiałów regionalnych (małych ojczyzn), powoduje uruchamianie strumieni środków zewnętrznych na digitalizację. Wymusiło to także stworzenie polityki digitalizacyjnej, którą Biblioteka od kilku lat z powodzeniem realizuje. 
Biblioteka Uniwersytecka jest aktywnym partnerem uczelni w roli koordynatora projektów uniwersyteckich. Działania Biblioteki w tym zakresie przyczyniły się do stworzenia pierwszego w Polsce repozytorium instytucjonalnego AMUR oraz platformy czasopism elektronicznych wydawanych na Uniwersytecie im. Adama Mickiewicza - PRESSto.

Czynności związane $\mathrm{z}$ budową repozytorium prowadzone między 2008 a 2010 rokiem rozpoczęły publiczną dyskusję uczelnianą o konieczności publikowania w modelu open access i znaczeniu promocji dorobku pracowników naukowych na arenie międzynarodowej za pośrednictwem platform elektronicznych.

Bibliotekarze, uczestnicząc $w$ obradach senatu uczelni, radach wydziałów, spotykając się indywidualnie z kadrą akademicką, przekonywali do zasadności wdrożenia platformy i wprowadzenia optymalnej polityki funkcjonowania repozytorium. W konsekwencji zainstalowano i skonfigurowano dedykowane oprogramowanie open source - Dspace (autorstwa Massachusetts Institute of Technology), z rozszerzoną funkcjonalnością zbierania danych statystycznych. Wsparciem otrzymanym ze strony władz rektorskich było wydanie zarządzenia dotyczącego obligatoryjnego deponowania na platformie prac doktorskich oraz zachęta skierowana do pracowników nauki, aby decydowali się na autoarchiwizację swoich artykułów. Dzięki działaniu zainicjowanemu przez Bibliotekę Uniwersytet im. Adama Mickiewicza w Poznaniu zaczął znacznie awansować w rankingach webometrycznych. Według raportu światowego rankingu repozytoriów - The Ranking Web of World Repositories - repozytorium AMUR na początku 2015 roku znalazło się na 155. miejscu wśród 2154 indeksowanych repozytoriów z całego świata. Wśród polskich repozytoriów AMUR od kilku lat zajmuje pierwszą pozycję.

W roku 2014 Biblioteka Uniwersytecka podjęła się zadania związanego z przekształceniem czasopism wydawanych na Uniwersytecie im. Adama Mickiewicza w profesjonalne czasopisma elektroniczne. W tym celu przysposobiła dedykowane oprogramowanie Open Journal Systems, do prezentacji wspólnej bazy kilkudziesięciu czasopism UAM. Każde z nich otrzymało swoją elektroniczną przestrzeń do prezentacji polityki funkcjonowania, w tym przedstawienia celu i zakresu tematycznego publikowanych materiałów, procesu recenzji, polityki open access czy prywatności. W obszarze informatycznym wdrożenie platformy czasopism polegało na zainstalowaniu najnowszej wersji oprogramowania, prowadzeniu zaawansowanych prac konfiguracyjnych i administracyjnych, dokonaniu profesjonalnego spolszczenia platformy, ustaleniu elementów składowych, skonfigurowaniu modułów, a także na przetestowaniu 
poprawności funkcjonowania oprogramowania. Równolegle trwały prace nad zaprojektowaniem i przygotowaniem layoutu platformy oraz dodaniem elementów graficznych wyróżniających system. Uruchomiono też dodatki umożliwiające zliczanie statystyk, eksport danych do bazy repozytorium instytucjonalnego czy aktywacji numerów DOI. Biblioteka jest odpowiedzialna za ustanowienie polityki funkcjonowania platformy PRESSto oraz administrację, rozwój i wsparcie redakcji w jej obsłudze, a także doradztwo i pomoc $\mathrm{w}$ dostosowaniu czasopism do międzynarodowych standardów elektronicznych publikacji naukowych i wymogów najważniejszych baz indeksujących. Koordynacją tych działań zajmuje się menedżer platformy.

Partnerstwo ze środowiskiem bibliotecznym w Polsce, w realizacji projektów analitycznych, można dostrzec na przykładzie tworzonej od 2002 roku na wzór rozwiązań światowych „Analizy Funkcjonowania Bibliotek Naukowych". To przedsięwzięcie służy badaniom ilościowym i jakościowym wszystkich obszarów aktywności bibliotek akademickich w Polsce, ma na celu wyliczanie wskaźników funkcjonowania i wypracowanie krajowych standardów bibliotecznych w obrębie bibliotek naukowych. Biblioteka Uniwersytecka, jako koordynator, bierze udział w zespole badawczym, administruje infrastrukturą informatyczną, a więc zapewnia środowisko sprzętowe do posadowienia bazy danych, nadzoruje i aktualizuje program komputerowy oraz prowadzi stałe wsparcie techniczne w zakresie modyfikacji elektronicznych formularzy czy też korekty i zatwierdzania danych $\mathrm{z}$ ankiet nadsyłanych z ponad 60 polskich bibliotek naukowych.

\section{"Chmury" nad Biblioteką}

Podsumowanie okresu komputeryzacji Biblioteki Uniwersyteckiej nie jest zadaniem łatwym. Wspomniane w tym artykule działania wydają się najistotniejsze z punktu widzenia organizacji i zarządzania procesami bibliotecznymi. Z informatyzacją w Bibliotece Uniwersyteckiej można się spotkać już po wejściu do gmachu, gdzie elektroniczne czujniki rejestrują liczbę odwiedzin, a drzwi automatycznie blokują się po wzbudzeniu bramki zabezpieczającej księgozbiór. Kamery rozlokowane w budynku eliminują próby kradzieży, a elektroniczne systemy identyfikacyjne oddzielają strefy ogólnodostępne od przestrzeni zastrzeżonej wyłącznie dla personelu. Klimatyzatory optymalizują warunki przechowywania cymeliów, a UPS'y dbają o stabilne funkcjonowanie serwerów i stacji roboczych oraz chronią przed awariami sieci energetycznej. 
Przez ostatnie lata Biblioteka nie szczędziła środków na rozwój informatyczny i, będąc instytucją otwartą na zmiany, stała się liderem we wdrażaniu nowych technologii. Niestety, poniosła też koszt wirtualizacji usług w postaci zmniejszającej się liczby użytkowników odwiedzających czytelnie, chociaż śledząc raporty bibliotek zachodnich, widać, że jest to tendencja ogólnoświatowa ${ }^{12}$.

Dziś, w czasie zmian organizacyjnych na Uniwersytecie im. Adama Mickiewicza, dokonano modyfikacji w zakresie nadzoru nad siecią komputerowa, serwerami i stacjami roboczymi. Zgodnie z decyzjami rektorskimi pełną odpowiedzialność za urządzenia sieciowe Biblioteki przejęło Centrum Zarządzania Infrastrukturą i Projektami Informatycznymi UAM, do którego przeniesiono także większość serwerów, eliminując $\mathrm{w}$ ten sposób nakłady na rozbudowę bibliotecznej serwerowni. W działaniu tym Biblioteka nie upatruje zagrożenia, ale szansę na zapewnienie jeszcze większego bezpieczeństwa aplikacji i danych, co w dobie zagrożeń cyberatakami jest niezmiernie ważne.

Choć dynamika zmian w zakresie technologii informatycznych wyklucza możliwość kreślenia długookresowej strategii rozwoju komputeryzacji, to biorąc pod uwagę dotychczasowe zaangażowanie Biblioteki Uniwersyteckiej we wdrażaniu innowacji, opracowana zostanie perspektywa zmian w ciągu kilku najbliższych lat. Przyglądając się rozwiązaniom zachodnim, można założyć, że rozwój bibliotek będzie ukierunkowany na projektowanie i uruchamianie większej liczby usług wirtualnych, szczególnie dostępnych w technologii mobilnej. Biblioteki będą projektować i wdrażać dla czytelników aplikacje na smartfony i tablety, wykorzystując GPS, kamery, NFC itp. Portal biblioteczny będzie jeszcze bardziej intuicyjny i sprofilowany pod indywidualne oczekiwania użytkownika. Otrzyma on w ten sposób błyskawiczny dostęp do potrzebnych mu informacji i usług. Dotychczasowe systemy biblioteczne klient-serwer zostaną zmienione $\mathrm{w}$ produkty nowej generacji, zbudowane $\mathrm{w}$ architekturze cloudcomputing. W związku z olbrzymim przyrostem danych cyfrowych w systemach tych będzie można zarządzać kolekcjami elektronicznymi, zapewniając ich gromadzenie, opracowanie i udostępnianie. Uniwersalność programów bibliotecznych wyeliminuje konieczność ponoszenia nakładów na administrację niezależnymi platformami dedykowanymi repozytoriom czy bibliotekom cyfrowym. Biblioteki staną przed koniecznością poszukiwania rozwiązań gwarantujących bezpieczeństwo danych w "chmurze", a także opracowywania procedur w przypadku zmiany

12 C. Beard, D. Bawden, University libraries and the postgraduate student: physical and virtual spaces, „New Library World” 2012, nr 113 (9/10), s. 439-447. 
producenta systemu bibliotecznego. Bibliotekarz otrzyma dostęp do programu bibliotecznego przez stronę internetowa a tradycyjne moduły systemu zostaną zmienione $\mathrm{w}$ procesy, które $\mathrm{w}$ ramach obowiązków podejmować będzie personel Biblioteki. Nie zmienią się obowiązujące standardy opracowania metadanych, ale bardziej wyeksponowane zostaną narzędzia do importu danych z zewnętrznych baz, aby proces katalogowania przebiegał szybciej. Ponieważ dużą wagę będzie się przywiązywać do racjonalizowania wydatków na zakup zbiorów i subskrybowanie kolekcji elektronicznych, rozbudowane zostaną narzędzia statystyczno-analityczne. Użytkownik otrzyma do dyspozycji zaawansowane multiwyszukiwarki zasobów, które z poziomu jednej ramki wyszukiwawczej przeprowadzą proces selekcji i wyboru informacji z różnych źródeł elektronicznych (katalogów, baz, e-czasopism).

Pojawienie się systemów nowej generacji miało pomagać zachodnim bibliotekom akademickim w zapewnianiu tej samej, wysokiej jakości usług przy mniejszej obsadzie personelu ${ }^{13}$. Zatem tam, gdzie tylko możliwe, wykorzystywana jest $\mathrm{w}$ nich technologia informatyczna, a wykwalifikowani bibliotekarze podejmują się nowych zadań: są szkoleniowcami prowadzącymi zajęcia na uczelniach, partnerami dla naukowców w realizowanych przez nich grantach, zapewniają fachowe wsparcie w administracji repozytoriami czy też pomagają wydawnictwom akademickim i radom redakcyjnym. Można zatem przewidzieć zmiany w zakresie zarządzania zasobami ludzkimi również w Bibliotece Uniwersyteckiej w Poznaniu i należy już dziś się na nie przygotowywać.

Nowoczesny bibliotekarz będzie musiał być jeszcze bardziej otwarty na nowe technologie (znać je i wykorzystywać), gdyż dzięki nim informacja szybciej trafi do użytkownika i twórcy. Oprócz czerpania z gotowych aplikacji trzeba będzie umieć projektować własne, uwzględniając indywidualny charakter Biblioteki i oczekiwania czytelników. Utrzymanie wysokiej jakości usług będzie możliwe wyłącznie z bibliotekarzem profesjonalista, który śledząc aktualne rozwiązania bibliotek światowych w "swojej dziedzinie", spojrzy na instytucję nie przez pryzmat oddziału lub sekcji, w jakich pracuje, ale jako na informacyjne centrum obsługi uczelni ${ }^{14}$. Realizowane przez nie zadania będą się opierać właśnie na informatyzacji - nie tylko w obszarze formularzy wzorcowych opisów

${ }^{13}$ G. Munde, Everyday HR: A Human Resources Handbook for Academic Library Staff, 2013, http://search.ebscohost.com.ebookacademicsubscriptioncollection-worldwideidxi13035.bu-169.bu.amu.edu.pl/login.aspx?direct=true\&db=e000xww\&AN=789965 \&site=ehost-live [dostęp: 1.12.2015]

${ }^{14}$ J. Wusteman, Editorial. Virtual research environments, „Library Hi Tech” 2009, nr 27 (2), s. 169-173. 
bibliograficznych, ale też w aspekcie wyliczania i przekazywania do ministerstwa wskaźników dokonań naukowych, w eksporcie metadanych do systemów bibliograficznych, projektowaniu i tworzeniu multimedialnych kursów e-learningowych, przeprowadzanych szkoleniach wirtualnych dla naukowców i studentów, profesjonalnej analizie danych statystycznych z elektronicznych systemów.

Bibliotekarz, chcąc być partnerem dla współczesnego użytkownika, musi znać standardy tworzenia bibliografii załącznikowych, proponować adekwatne do dziedzin wiedzy międzynarodowe formaty cytowań, poszukiwać rozwiązań związanych z obsługą elektronicznego egzemplarza obowiązkowego, wirtualnej wypożyczalni międzybibliotecznej czy udostępniania treści elektronicznych na nośniki mobilne, z zachowaniem przepisów prawa autorskiego. Potrzeba więc permanentnego rozwoju własnych kompetencji zawodowych, aby podejmować nowe zadania, w dalszym ciągu rozumieć i realizować potrzeby informacyjne czytelnika, także wirtualnego.

\section{Bibliografia}

Aharony N., An analysis of American academic libraries' websites: 2000-2010, „The Electronic Library" 2012, nr 30 (6), s. 764-776.

Beard C., Bawden D., University libraries and the postgraduate student: physical and virtual spaces, „New Library World” 2012, nr 113 (9/10), s. 439-447.

Bolin M.K., Catalog design, catalog maintenance, catalog governance, „Library Collections, Acquisitions, and Technical Services" 2000, nr 24 (1), s. 53-63.

Caldwell-Stone D., Chapter 6: RFID in Libraries, "Library Technology Reports" 2010, nr 46 (8), s. 38, http://search.ebscohost.com.academicsearchcompleteide sx11478.bu-169.bu.amu.edu.pl/login. aspx?direct $=$ true $\& d b=f 5 h \& A N=55$ 483467\&site=ehost-live.

Chow A.S., Croxton R.A., A Usability Evaluation of Academic Virtual Reference Services, „College \& Research Libraries” 2014, nr 75 (3), s. 309-361.

Cox A.M., Corrall S., Evolving academic library specialties, "Journal of the American Society for Information Science and Technology" 2013, nr 64 (8), s. $1526-1542$.

Hollender H., Kasprzyk A., Library cooperation the Polish way: toward NUKAT and WorldCat in Poland, „New Library World” 2008, nr 109 (9/10), s. 457-465.

Karwasiński P., Karwasińska E., Libsmart Assistant - nowy standard komunikacji bibliotecznej w przestrzeni wirtualnej, w: IV Wroctawskie Spotkania Bibliotekarzy. Z problemów bibliotek naukowych Wroctawia 11, red. D. Dudziak, M. Ziółek, Wrocław 2014, s. 57-74.

Kilgour F.G., History of Library Computerization, „Information Technology and Libraries" 2013, nr 3 (3), s. 218-229. 
Munde G., Everyday HR: A Human Resources Handbook for Academic Library Staff, 2013, http://search.ebscohost.com.ebokacademicsubscriptioncollection-world wideidxi13035.bu-169.bu.amu.edu.pl/login.aspx?direct $=\operatorname{true} \& d b=e 000$ xww\&AN=789965\&site=ehost-live.

Nikisch J.A., Jakiego konsorcjum potrzebujemy i jakie mamy? Z doświadczeń Poznańskiej Fundacji Bibliotek Naukowych, „EBIB Elektroniczny Biuletyn Informacyjny Bibliotekarzy" 2002, nr 7 (36), http://www.ebib.pl/2002/36/nikisch.php.

Wilson T.C., The Systems Librarian: Designing Roles, Defining Skills, 1998, http:// search.ebscohost.com.ebookacademicsubscriptioncollection-worldwide idxi13031.bu-169.bu.amu.edu.pl/login.aspx?direct=true\&db=e000xww\&AN= 45033\&site $=$ ehost-live.

Wusteman J., Editorial. Virtual research environments, „Library Hi Tech” 2009, nr 27 (2), s. 169-173.

Yang S.Q., Dalal H.A., Delivering Virtual Reference Services on the Web: An Investigation into the Current Practice by Academic Libraries, „The Journal of Academic Librarianship" 2015, nr 41 (1), s. 68-86.

\title{
PIOTR KARWASIŃSKI, HANNA WESOŁOWSKA-MIS
}

\section{The influence of informatisation of Poznań University Library upon organizational changes and development of library services}

\begin{abstract}
Aвstract. The article discusses problems and issues relative to automation processes at Poznań University Library. To provide a more in-depth insight into the nature of the changes, these solutions that distinctively improved the quality of work of the staff and user services are presented, beside the record of consecutive changes introduced to the library. These changes have facilitated the general knowledge of new technological solutions, their implementation and the resulting widespread use. The process of the changes in the operation of the Horizon library integrated system is presented as well as the Library's cooperation with the national central catalogue NUKAT. Successive stages in the development of electronic information space are described, including the creation of electronic knowledge resources and tools to handle them in the process of searching for information sources. The University Library is presented as a partner in preparing and implementing institutional digital platforms used in submitting and making available the research output of the University's academic community to the general public. Finally, the functionality of the already implemented innovative virtual services of the Libsmart package that streamlines the operation of the University Library is presented.
\end{abstract}

KEY wORDs: automation, virtual services, cloud, electronic library, virtual users, Libsmart. 